\title{
Розділ 1
}

\section{АКТУАЛЬНІ ПРОБЛЕМИ ВИЩОЇ ШКОЛИ CHAPTER 1 ACTUAL ISSUES OF THE HIGHER EDUCATION}

УДК 378.126

\author{
DOI: 10.31376/2410-0897-2018-3-38-12-18 \\ Юрій Андрійович Скиба, \\ доктор педагогічних наук, доцент, головний науковий \\ співробітник відділу інтеграції вищої освіти і науки \\ Інституту вищої освіти НАПН України, \\ e-mail: yuri_skiba@ukr.net
}

\section{ДОСВІД РОЗРОБЛЕННЯ ПРОФЕСІЙНИХ СТАНДАРТІВ І ПРОФІЛІВ НАУКОВО- ПЕДАГОГІЧНИХ ПРАЦІВНИКІВ ЗАКЛАДІВ ВИЩОЇ ОСВІТИ В КРАЇНАХ БЛИЗЬКОГО ЗАРУБІЖЖЯ}

У статті проаналізовано особливості і структуру професійних стандартів науково-педагогічних працівників закладів вищої освіти країн близького зарубіжжя. Встановлено, щзо в основу розроблення професійних стандартів науково-педагогічних працівників покладено функиіональний принцип. Виявлено особливості вимог до різних категорій науково-педагогічних прачівників (асистента, викладача, стармого викладача, дочента, професора), зокрема до освіти, досвіду роботи, знань та вмінь. Встановлено, які трудові функиії мають виконувати різні категорії науково-педагогічних праиівників. На основі аналізу трудової функиії «викладання навчальних предметів, курсів, дисииплін (модулів) або окремих видів навчальних занять» розкрито вимоги до знань і вмінь різних категорій науково-педагогічних прачівників. 3'ясовано, що асистент, викладач і старший викладач може здійснювати професійну діяльність тільки на першому (бакалаврському) рівні вищої освіти, доцент - на першому (бакалаврському) $i$ другому (магістерському) рівнях вищої освіти, професор - на третьому (освітньо-науковому) і науковому рівнях витої освіти.

Ключові слова: професійний стандарт, професійний профіль, трудові функції, професійні вимоги, посада, науково-педагогічні прачівники, заклад вищої освіти.

Постановка проблеми. Глобалізація та інтернаціоналізація вищої освіти потребують адаптації вітчизняного освітнього законодавства до загальних принципів та практик, що використовують у світі. Одним із напрямів державної політики європейських країн у сфері вищої освіти є стандартизація вимог до професійних компетентностей науково-педагогічних працівників. Тому вивчення $\mathrm{i}$ використання закордонних практик щодо розроблення професійних стандартів і профілів науково-педагогічних працівників може вберегти від помилок та сприятиме успішній реалізації реформ у сфері вищої освіти в Україні.

Аналіз останніх досліджень і публікацій. Теоретичні основи розроблення професійних стандартів і профілів знайшли відображення у працях таких науковців близького зарубіжжя: Б. Бєлкова (особливості професійних і освітніх стандартів), В. Блінова, Л. Гребнєва (роль професійних стандартів у проектуванні моделі професійної підготовки майбутнього спеціаліста), В. Довгого, В. Зарубіна, О. Начкіна (економічні аспекти професійного профілю), О. Крилової, О. Даутової (підходи до розроблення профілю компетентностей науково-педагогічного працівника), М. Ларіонової (стратегія професійного розвитку науково-педагогічних працівників), Н. Машукової (сутність і призначення професійних стандартів), Н. Третьякової, В. Федорова (професійні функції науково-педагогічних працівників).

Проведемо аналіз наукових праць деяких авторів. Здійснені О. Криловою та О. Даутовою дослідження дали їм змогу 3'ясувати функції профілю науково-педагогічного працівника та встановити перелік компетентностей відповідно до його професійної діяльності. На переконання авторів, профіль виконує низку функцій: «... сприяє розвитку професійних умінь і навичок, $є$ інструментом ідентифікації потенційних точок зростання і професійного розвитку науково-педагогічного працівника, а також діагностичним інструментом роботодавця при прийомі на роботу» [3, с. 14]. У профілі авторами виділено такі категорії: науководослідницька діяльність, викладацька діяльність, професійно-особистісний саморозвиток, соціальнопрофесійна взаємодія і комунікація. У межах означених категорій виокремлено 16 компетентностей [3, с. 12$].$ 
Проте означені компетентності не відображено у розробленому професійному стандарті.

Важливу роль у розробленні професійного профілю і стандарту науково-педагогічного працівника відіграє розуміння стратегії його розвитку. М. Ларіонова виокремлює дві стратегії професійного розвитку науково-педагогічного працівника закладу вищої освіти, зокрема формалізовану та перетворювальну. Особлива увага у стратегії перетворювального професійного розвитку науково-педагогічного працівника повинна приділятися «...перш за все його бажанню до самозміни в підвищенні ефективності багатоаспектної професійно-педагогічної діяльності, у визначенні смислу і значення професії, професійного спілкування для себе в контексті життєдіяльності. Суб'єктність науково-педагогічного працівника розглядається через ... розкриття його особистісних властивостей, способів і можливостей» [3, с. 132]. Тому, на наше переконання, під час розроблення професійного профілю науково-педагогічного працівника доцільно орієнтуватися на стратегію перетворювального професійного розвитку.

Ураховуючи, що професійний профіль виконує низку функцій на переконання В. Зарубіна i О. Начкіна [2], В. Довгого [1], одним із ефективних механізмів розвитку професійних компетентностей, наукової самореалізації, професійного і кар'єрного зростання є впровадження для науково-педагогічних працівників закладів вищої освіти ефективного контракту. «Оскільки ефективний контракт - механізм оплати праці, орієнтований на результат, який включає показники наукової, викладацької та експертної діяльності» [2, с. 50]. Його впровадження сприятиме інституціональним змінам у галузі вищої освіти, зокрема вмотивованості наукових педагогічних працівників до професійного саморозвитку, підвищення власної конкурентоспроможності та мобільності в університетському співтоваристві.

Тому вивчення практик розроблення професійних стандартів і профілів науково-педагогічних працівників закладів вищої освіти має важливе значення для успішної реалізації освітніх реформ в Україні.

Мета статті - проаналізувати професійні стандарти і профілі науково-педагогічних працівників закладів вищої освіти країн близького зарубіжжя для 3'ясування структури, принципів їх розроблення $\mathrm{i}$ виявлення їх інваріантних складових.

Виклад основного матеріалу. Проведено аналіз професійних стандартів науково-педагогічних працівників країн близького зарубіжжя [5]. Встановлено, що в основу їх розроблення покладено функціональний підхід. Відповідно до визначених функцій у них подано деталізований перелік необхідних знань та вмінь претендентів на різні посади науково-педагогічних працівників, водночас відсутній перелік компетентностей, якими вони мають володіти.

У стандартах визначено, що основними освітніми вимогами, якими мають володіти претенденти на відповідну посаду науково-педагогічного працівника, $\epsilon$ наявність диплома про вищу освіту (програма магістратури, аспірантури, асистентури-стажування, докторантури), як правило, відповідно до спрямованості (профілю) освітньої програми вищої освіти.

Крім того, визначено вимоги до досвіду практичної роботи. Так, до претендента на посаду асистента вимог до стажу роботи не висувається; викладача - стаж роботи в освітній організації не менше 1 року, при наявності наукового ступеня кандидата наук - без вимог до стажу роботи; старшого викладача - стаж науково-педагогічної роботи не менше 3 років, при наявності вченого ступеня кандидата наук стаж науковопедагогічної роботи не менше 1 року; доцента - стаж науково-педагогічної роботи не менше 3 років або науковий ступінь кандидата (доктора) наук, вчене звання доцента; професора - для викладання за програмами аспірантури (ад'юнктури): стаж науково-педагогічної роботи не менше 5 років і вчений ступінь доктора наук або вчене звання професора, досвід організації та здійснення науково-дослідницької діяльності, підтверджений публікаціями за ії результатами в провідних вітчизняних та (або) зарубіжних рецензованих наукових журналах і виданнях, а також участю в національних та міжнародних конференціях.

Аналіз професійних стандартів науково-педагогічних працівників дав змогу виявити трудові функції, які має виконувати асистент, викладач і старший викладач [5], а саме:

- Викладання навчальних предметів, курсів, дисциплін (модулів) або окремих видів навчальних занять.

- Участь в організації науково-дослідницької, проектної, навчально-професійної та іншої діяльності (навчаються під керівництвом фахівця вищої кваліфікації).

- Розроблення під керівництвом фахівця вищої кваліфікації навчально-методичного забезпечення реалізації навчальних предметів, курсів, дисциплін (модулів) або окремих видів навчальних занять.

освіти.

- Створення педагогічних умов для розвитку груп (курсів), які навчаються за програмами вищої

- Проведення профорієнтаційних заходів зі школярами та їхніми батьками.

Проте здійснювати професійну діяльність асистент, викладач і старший викладач можуть тільки на першому (бакалаврському) рівні вищої освіти.

Для доцентів у професійних стандартах передбачені такі трудові функції [5]: 
- Викладання навчальних предметів, курсів, дисциплін (модулів) за програмами бакалаврату, магістратури.

- Професійна підтримка фахівців, що беруть участь у реалізації своїх підшефних навчальних предметів, курсів, дисциплін (модулів), організації навчально-професійної, дослідницької, проектної та іншої діяльності (навчаються за програмами вищої освіти).

- Керівництво науково-дослідницькою, проектною, навчально-професійною та іншою діяльністю (навчаються за програмами бакалаврату, магістратури).

- Розроблення науково-методичного забезпечення для реалізації відповідних навчальних дисциплін, курсів, модулів.

- Створення педагогічних умов для розвитку групи (курсу) (навчаються за програмами вищої освіти).

- Проведення профорієнтаційних заходів зі школярами та їхніми батьками.

Доцент здійснює викладацьку діяльність як на бакалаврському, так і на магістерському рівнях. Водночас він здійснює професійну підтримку асистента, викладача та старшого викладача 3 навчальних дисциплін або модулів, які сам викладає.

Професор має виконувати такі трудові функції відповідно до професійних стандартів [5]: вищої кваліфікації.

- Викладання навчальних предметів, курсів, дисциплін (модулів) за програмами підготовки кадрів

- Керівництво групою фахівців, що беруть участь у реалізації освітніх програм вищої освіти.

- Керівництво підготовкою аспірантів за індивідуальним навчальним планом.

- $\quad$ Розроблення науково-методичного забезпечення для реалізації програм підготовки кадрів вищої кваліфікації для осіб, які мають або отримують відповідну кваліфікацію. вищої освіти.

- Створення педагогічних умов для розвитку груп (курсів), що навчаються за програмами другої

- $\quad$ Проведення профорієнтаційних заходів зі школярами та їхніми батьками.

Варто зазначити, що професори здійснюють підготовку кадрів вищої кваліфікації таһабо викладають здобувачам другої вищої освіти.

Розглянемо трудову функцію «викладання навчальних предметів, курсів, дисциплін (модулів) або окремих видів навчальних занять» професійних стандартів науково-педагогічних працівників для з'ясування вимог до вмінь і знань для різних категорій науково-педагогічних працівників (див. табл. 1).

Перелік вимог до вмінь і знань для різних категорій

Таблиця 1

\section{науково-педагогічних працівників для реалізації трудової функції «викладання навчальних} предметів, курсів, дисциплін (модулів) або окремих видів навчальних занять» [5]

\begin{tabular}{|c|c|c|c|c|c|}
\hline Необхідні вміння & 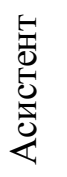 & 穿 & 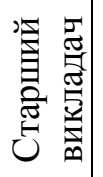 & 寗 & 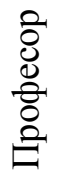 \\
\hline $\begin{array}{l}\text { Використовувати педагогічно обгрунтовані форми, методи, способи і } \\
\text { прийоми організації аудиторної та самостійної роботи студентів. }\end{array}$ & + & + & + & + & + \\
\hline $\begin{array}{l}\text { Застосовувати освітні технології, у тому числі інтерактивні, імітаційні, } \\
\text { інформаційні. }\end{array}$ & + & + & + & + & + \\
\hline $\begin{array}{l}\text { Здійснювати педагогічну підтримку професійного самовизначення і } \\
\text { професійного розвитку студентів бакалаврату. }\end{array}$ & + & + & + & & \\
\hline Вносити корективи в робочу програму, план вивчення куру. & + & + & + & & \\
\hline $\begin{array}{l}\text { Ефективно і якісно виконувати освітню діяльність, передбачену } \\
\text { програмою навчального предмета, курсу, дисципліни (модуля) } \\
\text { програм бакалаврату, магістратури. }\end{array}$ & & & & + & \\
\hline Встановлювати педагогічно доцільні відносини зі студентами. & & & & + & + \\
\hline $\begin{array}{l}\text { Створювати на заняттях проблемно орієнтоване освітнє середовище, } \\
\text { що забезпечує формування у студентів компетенцій, передбачених } \\
\text { освітнім стандартом, встановленим вищим навчальним закладом, і } \\
\text { (або) освітньою програмою. }\end{array}$ & & & & + & + \\
\hline $\begin{array}{l}\text { Здійснювати педагогічну підтримку професійного самовизначення і } \\
\text { професійного розвитку студентів, що навчаються за програмами } \\
\text { бакалаврату, магістратури. }\end{array}$ & & & & + & \\
\hline
\end{tabular}


Залучати студентів до профорієнтаційної роботи зі школярами та їхніми батьками.

Ознайомлювати студентів 3 досвідом успішних професіоналів, які працюють у відповідній галузі, корпоративною культурою підприємств-партнерів, вводити ії елементи в освітнє середовище.

Організовувати проведення конференцій, виставок, конкурсів професійної майстерності, інших конкурсів та аналогічних заходів (за профілем викладання навчального предмета, курсу, дисципліни (модуля)).

Готувати студентів до участі в конференціях, виставках, конкурсах професійної майстерності, інших конкурсах та аналогічних заходах (за профілем викладання навчального предмета, курсу, дисципліни (модуля))

Контролювати виконання на заняттях санітарно-гігієнічних норм i правил, правил пожежної безпеки, електробезпеки та ін.

Здійснювати поточний і підсумковий контроль, оцінювати динаміку підготовленості та мотивації студентів до вивчення навчального предмета, курсу, дисципліни (модуля).

Використовувати педагогічно обгрунтовані форми, методи, способи i прийоми організації контролю і оцінювання вивченого навчального предмета, курсу, дисципліни (модуля), застосовувати сучасні контрольно-вимірювальні та контрольно-оцінювальні засоби, забезпечувати об'єктивність оцінювання, здійснювати публічне представлення результатів оцінювання.

Вносити корективи в робочу програму, план вивчення курсу, дисципліни (модуля), освітні технології, власну професійну діяльність на підставі аналізу освітнього процесу і його результатів.

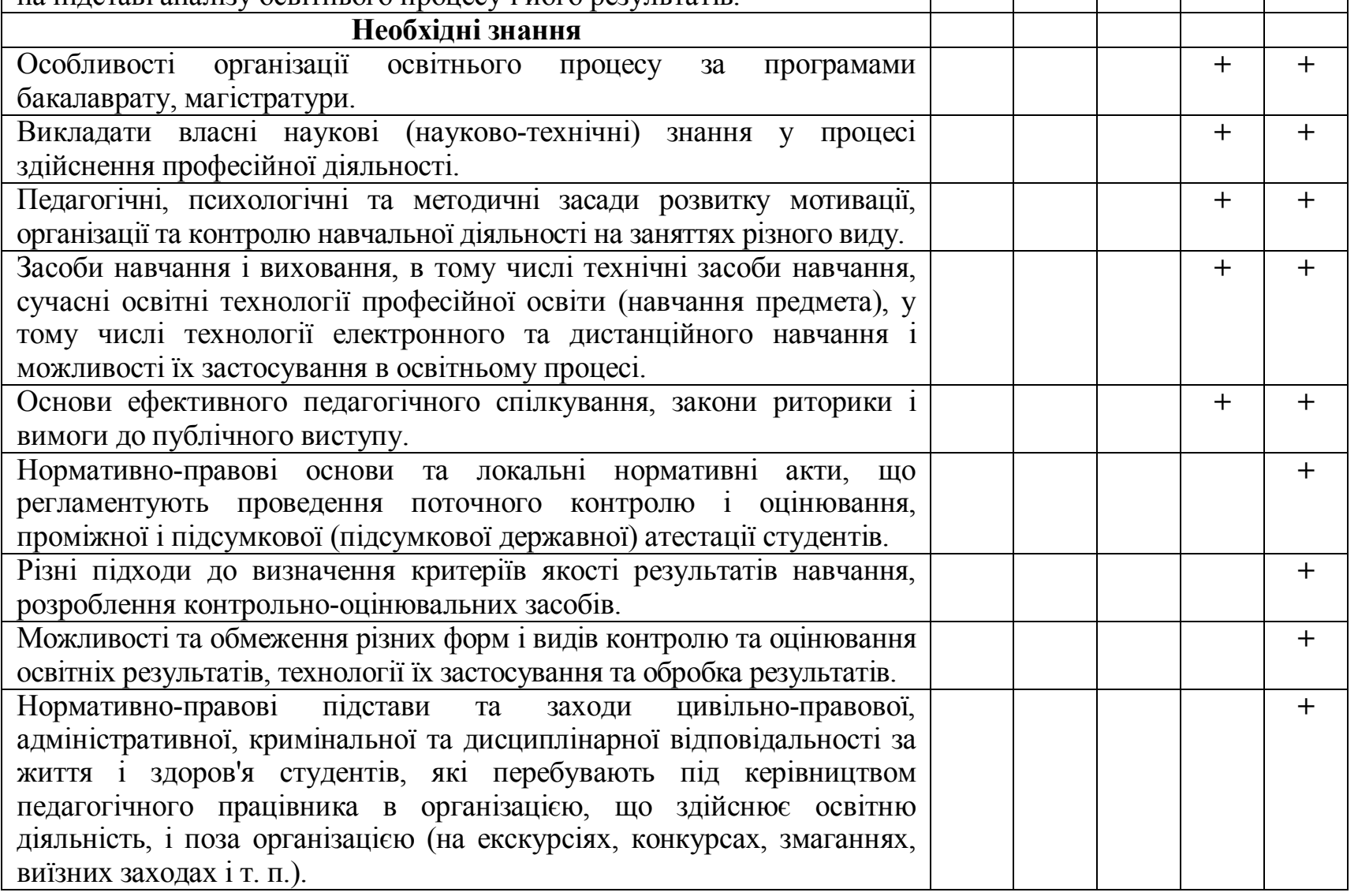

Проаналізувавши дані табл. 1, ми виявили тенденцію до ускладнення вимог до претендентів на вищі посади науково-педагогічних працівників. Так, асистент, викладач і старший викладач можуть здійснювати освітній процес тільки на рівні бакалаврату, доцент - на рівнях бакалаврату і магістратури, а професор - при підготовці наукових кадрів вищої кваліфікації та при підготовці здобувачів другої вищої освіти. 
Встановлено суттєві відмінності у посадах щодо вимог до необхідних знань та вмінь. Насамперед знаннями і вміннями, якими володіють асистент, викладач і старший викладач, мають володіти доцент i професор. Крім того, доцент повинен уміти здійснювати педагогічну підтримку професійного самовизначення і професійного розвитку студентів, які навчаються за програмами бакалаврату, магістратури; ознайомлювати студентів 3 досвідом успішних професіоналів, які працюють у відповідній галузі, корпоративною культурою підприємств-партнерів, вводити елементи корпоративної культури в освітнє середовище; організовувати проведення конференцій, виставок, конкурсів професійної майстерності, інших конкурсів та аналогічних заходів (за профілем викладання навчального предмета, курсу, дисципліни (модуля)); готувати студентів до участі в конференціях, виставках, конкурсах професійної майстерності, інших конкурсах та аналогічних заходах (за профілем викладання навчального предмета, курсу, дисципліни (модуля)).

Професор на відміну від інших категорій науково-педагогічних працівників повинен знати нормативно-правові основи та локальні нормативні акти, що регламентують проведення поточного контролю і оцінювання, проміжної і підсумкової (підсумкової державної) атестації студентів; різні підходи до визначення критеріїв якості результатів навчання, розроблення контрольно-оцінювальних засобів; можливості та обмеження різних форм і видів контролю та оцінювання освітніх результатів, технології їх застосування та обробки результатів; нормативно-правові підстави та заходи цивільно-правової, адміністративної, кримінальної та дисциплінарної відповідальності за життя і здоров'я студентів, які перебувають під керівництвом педагогічного працівника в організації, що здійснює освітню діяльність, i поза ії межами (на екскурсіях, конкурсах, змаганнях, виїзних заходах і т. п.).

Висновки. Здійснений аналіз професійних стандартів країн близького зарубіжжя свідчить про використання функціонального підходу до їх розроблення. Крім того, встановлюються вимоги до рівня кваліфікації претендентів, а також до знань та вмінь різних категорій науково-педагогічних працівників. На наше переконання, такий підхід не відображає якими саме компетентностями мають володіти претенденти на посади науково-педагогічних працівників закладів вищої освіти. Водночас ефективність оцінювальних інструментів при доборі кандидатів на посади науково-педагогічних працівників можуть давати суттєві похибки при визначенні професійних компетентностей кандидата. Водночас у професійних стандартах не вказано, якими особистісними якостями мають володіти претенденти на посади, наявність повного набору елементів професійних знань та вмінь співробітника може суперечити його особистісній поведінці, що нівелює цінність перших та перешкоджає ефективній реалізації його у практичній діяльності.

\section{Список використаних джерел та літератури}

1. Долгий В. И. Эффективный контракт и профессиональный профиль преподавателей высшей школы [Електронний ресурс] / В. И. Долгий. - Режим доступу: https://cyberleninka.ru/article/n/mnogomernyyanaliz-kachestva-professionalnoy-deyatelnosti-prepodavatelya-vysshey-shkoly. - Дата звернення: 03.09.2018.

2. Зарубин В. Г. Эффективный контракт научно-педагогического работника : нормативное и ценностное измерение [Електронний ресурс] / В. Г. Зарубин, А. И. Начкин // Ученые записки ЗабГУ. Социология - 2013. - С. 50-55. - Режим доступу: https://cyberleninka.ru/article/n/mnogomernyy-analizkachestva-professionalnoy-deyatelnosti-prepodavatelya-vysshey-shkoly. - Дата звернення: 07.09.2018.

3. Крылова О.Н. «Профиль компетенций» преподавателя высшей школы как инструмент его профессионального развития [Електронний ресурс] / О. Н. Крылова, О. Б. Даутова / Человек и образование. - 2016. - № 2 (47). - С. 11-14. - Режим доступу: https://cyberleninka.ru/article/n/mnogomernyy-analiz-kachestvaprofessionalnoy-deyatelnosti-prepodavatelya-vysshey-shkoly. - Дата звернення: 03.09.2018.

4. Ларионова М. А. Стратегия профессионального развития преподавателя [Електронний ресурс] / М. А. Ларионова // Омский научный вестник. Психологические и педагогические науки. -2009 . - № 1 (75). C. 129-133. - Режим доступу: https://cyberleninka.ru/article/n/mnogomernyy-analiz-kachestva-professionalnoydeyatelnosti-prepodavatelya-vysshey-shkoly. - Дата звернення: 25.08.2018.

5. Профессиональный стандарт преподавателя : проект [Електронний ресурс] - Режим доступу: http://www.tsuab.ru/upload/files/additional/ProfSt_file_553_2239_8400.pdf- Дата звернення: 25.08.2018.

\section{Юрий Андреевич Скиба,}

доктор педагогических наук, доцент, главный научный сотрудник отдела интеграции высшего образования и науки Института высшего образования НАПН Украины, e-mail: yuri_skiba@ukr.net

\section{ОПЫТ РАЗРАБОТКИ ПРОФЕССИОНАЛЬНЫХ СТАНДАРТОВ И ПРОФИЛЕЙ НАУЧНО- ПЕДАГОГИЧЕСКИХ РАБОТНИКОВ ВЫСШИХ УЧЕБНЫХ ЗАВЕДЕНИЙ В СТРАНАХ БЛИЖНЕГО ЗАРУБЕЖЬЯ}

В статье проанализированы особенности и структура профессиональных стандартов научно- 
педагогических работников высших учебных заведений стран ближнего зарубежья. Установлено, что в основу разработки профессиональных стандартов научно-педагогических работников положен функциональный принцип. Выявлены особенности требований к различным категориям научнопедагогических работников (ассистента, преподавателя, старшего преподавателя, доцента, профессора), к уровню образования, опьта работы, знаний и умений. Установлено, какие трудовые функции долюны выполнять различные категории научно-педагогических работников. На основе анализа трудовой функиии «преподавание учебных предметов, курсов, дисииплин (модулей) или отдельных видов учебных занятий» раскрыты требования к знаниям и умениям различных категорий научно-педагогических работников. Установлено, что ассистент, преподаватель и стариий преподаватель могут осуществлять свою профессиональную деятельность только на первом (бакалаврском) уровне высшего образования, доцент на первом (бакалаврском) и втором (магистерском) уровнях высшего образования, профессор - на третьем (образовательно-научном) и научном уровнях высшего образования.

Ключевые слова: профессиональный стандарт, профессиональный профиль, трудовые функции, профессиональные требования, должность, научно-педагогические работники, учреждение высшего образования.

\author{
Yuriy Skyba, \\ Doctor of pedagogical sciences, associate professor, \\ chief researcher of Department of Integration of Higher \\ Education and Science Institute of Higher Education of National \\ Academy of Pedagogical Sciences of Ukraine, \\ e-mail: yuri_skiba@ukr.net
}

\title{
EXPERIENCE OF DEVELOPING PROFESSIONAL STANDARDS AND PROFILES OF SCIENTIFIC AND PEDAGOGICAL WORKERS IN NEAR ABROAD HIGHER EDUCATIONAL INSTITUTIONS
}

Introduction. Globalization and the internationalization of higher education require the adaptation of domestic educational legislation to the general principles and practices that are used in the world. One of the directions of the state policy of European countries in the field of higher education is standardization of the requirements of professional competencies of scientific and pedagogical workers. That is why, studying and using of foreign practices in the sphere of development of professional standards and profiles of scientific and pedagogical workers can prevent mistakes and promote the successful implementation of reforms in the field of higher education in Ukraine.

Purpose. To analyze professional standards and profiles of scientific and pedagogical workers of institutions of higher education of the near-abroad countries in order to find out the structure, principles of their development and to identify their invariant components.

Methods. Analysis, synthesis, comparison to establish principles for the development of professional standards and profiles and modern professional requirements for different categories of scientific and pedagogical workers of institutions of higher education in the external middle countries.

Results. Features and structure of professional standards of scientific and pedagogical workers of institutions of higher education of the near abroad countries are analyzed.

Originality. There are defined the principles of developing professional standards of scientific and pedagogical workers, types of labor functions which they have to do. Identified the features of professional requirements for various categories of scientific and pedagogical workers (assistant, teacher, senior teacher, associate professor, professor) of institutions of higher education of close foreign countries, in particularly education, work experience, knowledge and skills.

Conclusion. The comparative analysis of the professional standards of the near abroad countries shows that there are identical approaches to their development, in particularly, using the functional approach, the definition of the level of qualifications, the selection of requirements for knowledge and skills of different categories of scientific and pedagogical workers. In our opinion, this approach does not reflect which competencies should be possessed by applicants for positions of scientific and pedagogical workers of institutions of higher education. At the same time, the effectiveness of assessment tools when selecting candidates for positions of scientific and pedagogical workers can cause significant errors in determining the professional competencies of the candidate. In addition, in professional standards there are no personal qualities of applicants for positions.

Key words: professional standard, professional profile, professional functions, professional requirements, position, scientific and pedagogical workers, institution of higher education.

\section{References}

1. Dolgiy V. I. Effektivnyiy kontrakt i proffesionalnyiy profil prepodavateley vyisshey shkolyi [Elektronnyiy resurs] / V. I. Dolgiy. - Rezhim dostupa : https://cyberleninka.ru/article/n/mnogomernyy-analizkachestva-professionalnoy-deyatelnosti-prepodavatelya-vysshey-shkoly. 
2. Zarubin V.G. Effektivnyiy kontrakt nauchno-pedagogicheskogo rabotnika : normativnoe i tsennostnoe izmerenie [Elektronnyiy resurs] / V.G. Zarubin, A.I. Nachkin // Uchenyie zapistki ZabGU. Sotsiologiya - $2013-$ S. 50-55. - Rezhim dostupa :https://cyberleninka.ru/article/n/mnogomernyy-analiz-kachestva-professionalnoydeyatelnosti-prepodavatelya-vysshey-shkoly.

3. Kryilova O.N. «Profil kompetentsiiy» prepodavatelya vyisshey shkolyi kak instrument ego professionalnogo razvitiya [Elektronnyiy resurs] / O.N. Kryilova, O.B. Dautova / Chelovek i obrazovanie. - 2016. - №2 (47). - S. 11-14. - Rezhim dostupa : https://cyberleninka.ru/article/n/mnogomernyy-analiz-kachestvaprofessionalnoy-deyatelnosti-prepodavatelya-vysshey-shkoly.

4. Larionova M.A. Strategiya professionalnogo razvitiya prepodavatelya [Elektronnyiy resurs] / M.A. Larionova // Omskiy nauchnyiy vestnik. Psihologicheskie i pedagogicheskie nauki. — 2009. - № 1 (75) S. 129-133 - Rezhim dostupa : https://cyberleninka.ru/article/n/mnogomernyy-analiz-kachestva-professionalnoydeyatelnosti-prepodavatelya-vysshey-shkoly.

5. Professionalnyiy standart prepodavatelya : proekt [Elektronnyiy resurs] - Rezhim dostupa : http://www.tsuab.ru/upload/files/additional/ProfSt_file_553_2239_8400.pdf

Отримано редакцією 20.09.2018 p.

УДК: 378.001.895

\title{
DOI: 10.31376/2410-0897-2018-3-38-18-25 \\ Тетяна Федорівна Зенченко,
}

кандидат педагогічних наук, старший викладач кафедри

педагогіки та менеджменту освіти Глухівського

національного педагогічного університету імені

Олександра Довженка,

e-mail: tatianazenchenko@ukr.net

\author{
Андрій Сергійович Литвинов, \\ кандидат педагогічних наук, старший викладач кафедри \\ педагогіки та менеджменту освіти Глухівського \\ національного педагогічного університету імені \\ Олександра Довженка, \\ e-mail: gnpu.edbo@gmail.com
}

\section{ПІДГОТОВКА МАЙБУТНІХ ФАХІВЦІВ ОСВІТНЬОГО МЕНЕДЖМЕНТУ НА ЗАСАДАХ КОМПЕТЕНТНІСНОГО ПІДХОДУ}

В статті охарактеризовано необхідність та иляхи формування здатності до інновачійної діяльності у майбутніх менеджерів освіти, як фахової компетентності. Окреслено основні фахові компетентності - здатності, необхідні для впровадження освітніх інновачій, самоосвіти та рефлексивного аналізу реального освітнього прочесу, визначено складники комплексного забезпечення використання освітніх інновачій. Встановлено, що одним із напрямів фундаменталізації підготовки магістра має стати організачійно-управлінський складник, упровадження якого забезпечуватиме розширення кола можливостей інноваційної професійної діяльності майбутнього фахівия галузі освіти.

Ключові слова: вища освіта, компетентність, здатність, інноваиійна діяльність, провайдинг освітніх інновацій, готовність, майбутній менеджер освіти.

Постановка проблеми. Рівень вищої освіти в Україні та ії вплив на фундаментальну професійну підготовку конкурентоспроможних на ринку праці фахівців значною мірою залежать від якості освітнього процесу у закладах вищої освіти, професійної компетентності викладачів, які забезпечують освітній процес у вищій школі, їхнього наукового потенціалу та педагогічної майстерності. Педагогічна діяльність викладачів ЗВО як вид професійної діяльності зі своїми специфічними особливостями має орієнтуватися на сучасні інноваційні та євроінтеграційні процеси в українському суспільстві та освіті, враховувати трансформаційні процеси вітчизняної вищої освіти, нову освітню парадигму та забезпечувати результат. Відповідно до цього вища освіта має створювати максимально сприятливі умови для підготовки майбутніх викладачів закладів вищої освіти, менеджерів освіти до управлінської, педагогічної та наукової діяльності.

3 огляду на визначені Національною рамкою кваліфікацій [10] базові компетентності магістра (знання, уміння, комунікація, автономність, відповідальність, інтегральна компетентність), вимоги до професійної діяльності фахівців такого рівня (розв'язання складних завдань і проблем у певній галузі професійної діяльності або у процесі навчання, проведення досліджень та використання освітніх інновацій, критичне осмислення наявних у професійній діяльності проблем; спроможність до прийняття рішень у складних та непередбачуваних ситуаціях; здійснення самостійного й автономного подальшого навчання), 